\title{
Supporting More Inclusive Learning with Social Networking: A Case Study of Blended Socialised Design Education
}

\author{
Russell Rodrigo \\ Tam Nguyen \\ Faculty of Built Environment \\ University of New South Wales, Australia \\ russell.rodrigo@unsw.edu.au
}

\begin{abstract}
This paper presents a qualitative case study of socialised blended learning, using a social network platform to investigate the level of literacies and interactions of students in a blended learning environment of traditional face-to-face design studio and online participatory teaching. Using student and staff feedback, the paper examines the use of a web-assisted model of assessment, participation and publication as a mechanism for measuring the effectiveness of inclusive learning when supported by the constructs of social interaction. This paper describes the analysis of qualitative data to develop a preliminary theoretical framework of the social affordances of web-assisted teaching environments to support the changing demands of student literacies, cultural competencies and learning needs. The framework aims to support future models of online learning and facilitate further research into mediated design education.
\end{abstract}

\section{Keywords}

Social media, blended learning, inclusive learning, design education

\section{Introduction}

Technology-enabled education is an extensive and active area of both research and current teaching. The use of Web 2.0 technologies, such as blogs and wikis, in the formal educational environment has made effective use of generational digital literacies and facilitated more flexible modes of learning. Challenges still exist, however, in areas of student equity and interpersonal relations. With the emergence of social networking, there is an increased level of personal interaction, accessibility and information management. This shift in the social landscape places demands upon teaching methods and student engagement, calling for ways to integrate the new social behaviour within the formal education setting.

During the past few years, an increasing number of Internet services are focusing on the practice of social behaviour using software that is perceived as socially connective, such as blogs, wikis, trackback, podcasting, video blogs and social networks like MySpace and Facebook (Alexander, 2006). This software, often categorised as Web 2.0 services, draw on individual production and user-generated content that is shared, tagged and published in a highly open, personalised manner 
(Andersen, 2007). Today's students are entering higher education as digital natives (Prensky, 2001), having grown up in a digital landscape for most of their lives. This generation of learners enter the university environment as multi-taskers, comfortable with performing multiple functions in various digital ways such as email, chat, text, and online posts (Roberts, 2005). Studies have shown that this level of online literacy places an increasing pressure on educators to integrate online tools to leverage this Internet-literate generation of learners.

One increasing global trend for Internet-based teaching delivery is the blended learning environment, which combines the online instructional system with face-to-face contact (Driscoll, 2002). Blended environments are often seen as a hybrid of two environments, one that employs conventional face-to-face interactions and one that utilises the Internet for extended communication and collaboration. Thus, blended environments present a flexible approach to course delivery offering more than one time and place for learning (Collis \& Moonen, 2002). Blended learning environments offer opportunities for social interactions to occur through reflective activity, collaboration and individual expression. According to social constructivist theory, higher levels of learning occur within this social context (Jusoff \& Khodabandelou, 2009; Yildiz, 2009), where interactions are promoted outside the face-to-face class time. In the Design Studio, recent case studies of blended approaches to design education have highlighted the importance of developing staff and student online proficiencies and the digitisation of studio tasks that are best supported by online media (Schnabel \& Ham, 2011; Osborne, Franz, Savage \& Crowther, 2011).

This paper documents a case study of blended socialised education in the First Year Design Studio. Initial findings from the study were presented at the $7^{\text {th }}$ International Conference of the Association of Architecture Schools of Australasia held in Melbourne, 3-5 October 2013.

\section{Study Aims}

The literature defines blended learning environments as achieved either through the blending of media or pedagogical approaches. In this study, the blended approach focused on the integration of the physical studio environment with an online studio environment.

The aims of the study were to:

- investigate patterns of student re-presentation, levels of disclosure, communal behaviour and social exchange in both the physical and virtual environments

- test whether a blended learning approach was able to facilitate a more effective and inclusive community of design inquiry

\section{Study Methodology and Sample}

A pilot study was conducted using a blended learning environment for first year students of an Interior Architecture design studio, combining the traditional face-to-face studio environment with an online studio environment using a social network platform. First year students $(n=92)$ from the Interior Architecture program were invited to participate in the survey. A brief analysis of the students showed the following details:

- $\quad 92 \%$ of students were aged under 24 years

- $70 \%$ stated they were local students, $30 \%$ were international.

- $75 \%$ of the students were female.

To assist in understanding the students' level of digital literacy, a number of multiple choice questions were posed to establish the existing online behaviour and experiences of the students. A brief analysis of the results showed the following details:

- $\quad 99 \%$ had access to computer at home for study

- $\quad 95 \%$ had used social media previously. An ensuing short answer question (with a response count of 88 ) revealed that $98 \%$ of this group of students stated Facebook as the primary type of social media they have used previously. 
- $\quad$ Outside the educational environment, $70 \%$ of students used social media on an everyday basis, $21 \%$ used social media a few times a week, $4 \%$ usually used it once a week, and $5 \%$ stated that they did not use it at all.

- Only 26\% had previously used an online learning environment for educational purposes. An ensuing short answer question (with a response count of 24) revealed a range of online learning environments, including Blackboard, Moodle, blogs, custom institutional LMS, and various websites.

These results show a high level of contact with social media and a familiarity with the digital medium. However, it also reveals that this experience occurs primarily outside the educational context.

Six tutors from the Interior Architecture studio were invited to participate in the survey. A brief analysis of the staff $(n=7)$ showed the following details:

- Four were female, three male

- $82 \%$ of staff over the age of 24

- $\quad 83 \%$ had access to computer at home

- $83 \%$ had used social media previously (Facebook)

- No staff member used social media outside the educational environment every day, $50 \%$ at least once per week

- Only $66 \%$ had previously used an online learning environment for educational purposes e.g., Blackboard in the university setting

- $60 \%$ of students logged into the on-line studio at least a few times per week

A key observation from the demographic data is the striking difference between the frequency of use of social media between students and staff. On a daily basis, $70 \%$ of students used social media (overwhelmingly Facebook) in contrast to $0 \%$ of staff. This is a reflection of of a key change in $21^{\text {st }}$ century information and communication channels - the prevalence of social network sites, particularly amongst younger generations.

\section{The Design Studio Environment}

The teaching of architectural design has remained relatively constant since the French École des Beaux-Arts was established in the 19th century. Central to teaching in architecture is the Design Studio, a unique learning environment that based in the tradition of "learning by doing" within a communal context. And, central to the effectiveness of the studio environment is the understanding that learning is a socialised activity; that a community needs to be formed for learning to take place. The design studio also begins the socialisation of students into the profession of architecture, developing an understanding of the social roles of players in the design process.

Design Studio forms the basis of teaching across all years of the Bachelor of Interior Architecture degree. Other mandatory courses such as communications, technology, history and theory develops knowledge and skills which support the learning outcomes of Design Studio. The first year Design Studio and Communications courses are fully integrated - technical skills developed in the communications course are choreographed with the development of higher order thinking and reflective skills in the Design Studio.

The face-to-face studio environment of First Year Design Studio is typical of most studio-based forms of design education. Tutorial groups are based around a maximum of fifteen students in a problem-solving setting led by individual tutors. Typically, studio activities begin with group pinups and discussions early in a project aimed at facilitating common understandings of design limits and possibilities and build to individual desk based consultations in the later stages of a project, aimed at refining design ideas. 


\section{The Online Studio Environment: Social Network Site}

A key aim of integrating the online environment with the traditional studio was the potential to add affordances that the face to face environment did not support well, such as connectedness between students and with the design process. Social network sites offer the potential for making these connections visible.

A social network site (SNS) is defined here as a web-based service that allow individuals to share content within a bounded system. Such systems can generally be constructed as either a public, semi-public or private profile, and aim to allow users to view and negotiate with their list of connections and those made by others within this system (boyd \& Ellison, 2008). A SNS was determined to be appropriate for the investigation of social behaviour of students within the formal educational environment.

Further to this, Ning, an online platform for the creating and hosting of social networks, was selected to host the course's online component. Selection criteria were primarily based on the level of:

- Usability: Ease of use was measured by the simplicity and aesthetics of the interface, for both staff and student.

- Social capacity: Social capacity included social features and terminology such as chat or discussion features, comments, "gifts," "friends," and updates.

- Administrative control: Administrative control included ease of use for course structuring, range of features and degree of design control.

- Privacy control: The platform had to provide privacy options, for both the course in general and specific features.

- Personalisation: The level of personalisation had to be high and include such features as avatars and personal profiles.

Ning competes with social sites such as Facebook and MySpace by allowing people with specific interests to create their own social networks using their own visual design, choice of functionality and member data. Ning was used to provide the online services for announcements, galleries of work and student blogs. Within five minutes of sending the invitations to the site, students had begun joining the network. Within $24 \mathrm{hrs}$, $90 \%$ of students had joined.

The following functionality was implemented in the on-line studio environment:

- Latest Activity: a central block of dynamic information, containing updates from blogs, events and comments. The latest activity was used as the first point of contact, to keep the student updated on what was occurring within the course.

- Blog: each member had a personal blog where individual content could be uploaded. The blog was used to house developmental work from studio projects. Blog entries were required on a weekly basis.

- Photo Gallery: used to store student albums containing scanned drawings, graphic layouts and imagery. Design studios involve a large amount of graphic communication, so the galleries allowed the students to upload a range of graphic content. This was a necessity, and a required component of the online environment.

- Comments: used to provide tutor feedback to specific posts, and an avenue for peer feedback. Comments were valued for their immediacy and connection to the relevant work.

- Events: simply used for announcements. However, the social terminology "events" altered the way the announcements were received.

- Individual User Page: Members had a personal page that contained their blogs, photo galleries, friends, and comments. This was used primarily to provide a high level of personalisation to the course.

- Chat: an opportunity for casual, unmonitored interaction between the students.

The on-line studio environment mimicked the face-to face environment through the establishment of "Groups" representing the tutorial groups $(n=7)$ led by specific tutors. As noted, students were 
required to maintain a weekly Blog using drawings, photos of virtual or physical models and text summarizing and reflecting on their design development. Tutors were requested to comment on the Blogs at least once prior to the weekly face-to-face studio. On first joining the network, users were requested to maintain all communication as "public" meaning that all users in the Ning community could view their profile, photos and blogs.

\section{Dynamic interface}

The interface of the Ning platform was designed to two primary criteria: visual appeal and social presence. Visual appeal included an easy to understand, simple layout that did not contain distracting or confusing imagery or colour schemes. Social presence here is defined as the "degree of salience of the other person in the interaction and the consequent salience of the interpersonal relationships" (Jusoff \& Khodabandelou, 2009, p. 79). It is also seen as the ability of learners to project themselves socially and affectively into a community of inquiry (Rourke, Anderson, Garrison, \& Archer, 1999). Social presence is a complicated construct and involves privacy, social relationships, communication styles, the nature of the task, feedback, and immediacy (Tu, 2002), and can have a significant impact on student progression, improved learning, motivation and engagement (Jusoff \& Khodabandelou, 2009; Richardson \& Swan, 2003). It is therefore necessary that a social presence can be sensed within an SNS.

The front page of the Ning network (Figure 1) was deliberately left minimal to place focus on the central block of information: the latest activity. Similar to other SNS, the latest activity block constantly changes with updates of activity from the network, including student blogs, events and comments. Network members are continuously being featured in this block, generating a strong sense of social presence. Other front-page items include personal settings, members, events, blogs and groups.

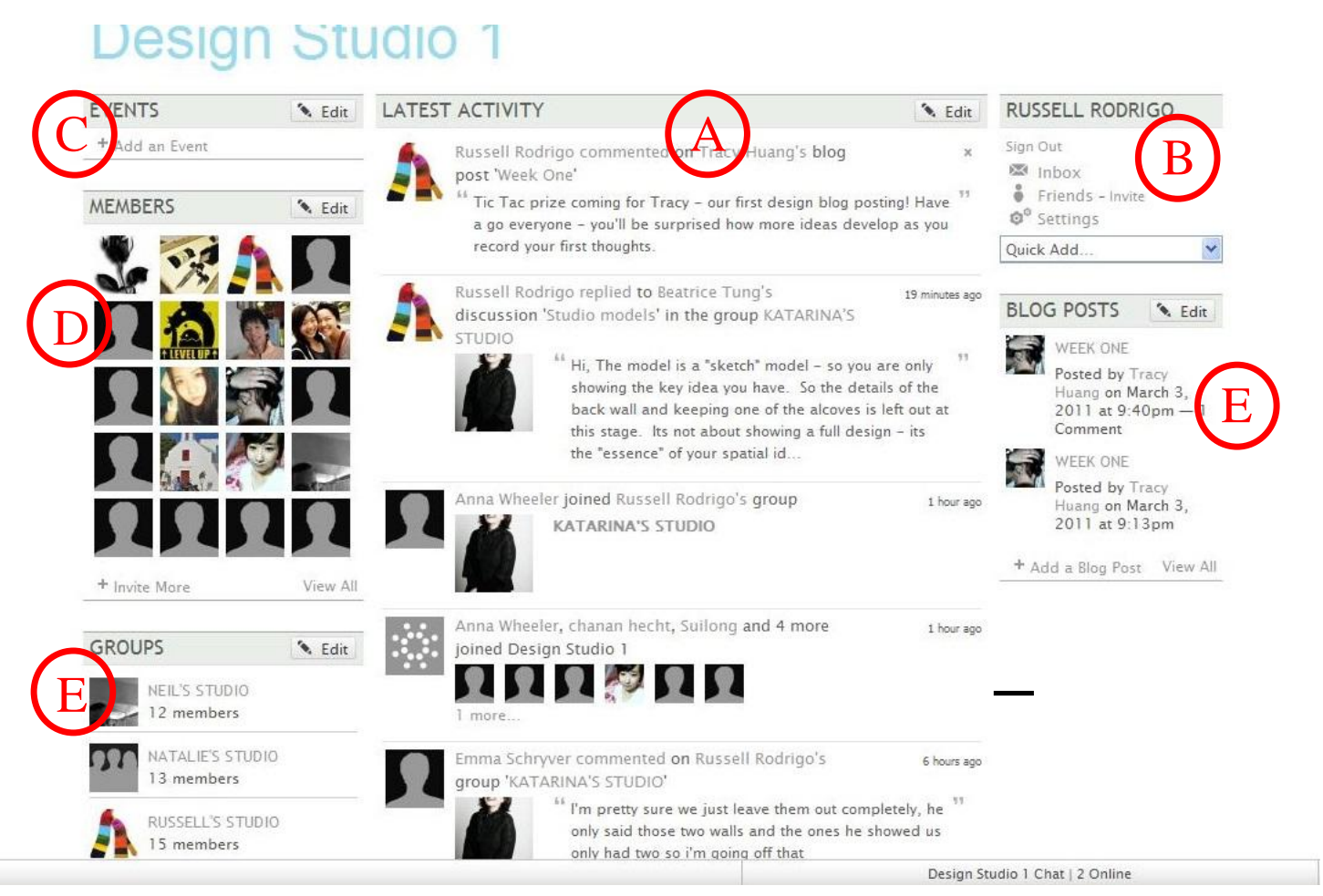

Figure 1. Components of the front page, Design Studio 1 Ning

Figure 1 shows the features, marked as A-E, included to facilitate social presence. These are: 
(A). Latest Activity feature block constantly updates with the activity of student blogs and comments

(B). Personal settings for every member, including email and list of friends

(C). Events feature block is used for announcements

(D). List of course members (students and tutors) displayed as customised avatars

(E). Features such as groups and blogs can be dragged onto the front page as condensed blocks

\section{Avatars, profiles and friends}

Like all social network sites, the Ning platform is built around the visible profile of members, including the listing of "Friends" who are also part of the system. Like most social network sites, Ning allows members to upload a profile photo, an avatar, as a representation of themselves. Students used this feature enthusiastically, with many regularly updating their avatars. Avatars emerged very quickly after the network was made active (Figure 2). Avatars for both students and staff ranged from full or partial portraits to more abstract images.

A critical component of all social network sites is the public display of socialisation and the making of connections. While all computer-mediated communication allows individuals to meet strangers, what makes social network sites different is that they "enable users to articulate and make visible their social networks" (boyd \& Ellison, 2008, p. 211). In the online studio environment, identity and connectedness is given visual and temporal form through the public displays of "friending," Donath and boyd noted that in social network sites, information is provided on an individual through the context of their connections, that is, "social status, political beliefs, musical taste, etc, may be inferred from the company one keeps" (Donath \& boyd, 2004, p. 72).

Like all social network sites, after joining the course Ning network, users were prompted to welcome new members and identify others they wish to make "Friends" with. The act of "making friends" was quickly adopted by students early in the course (Figure 3). The list of Friends also allowed users to cross the network by clicking through the Friends lists. Both the avatar and friend feature of Ning contributed to the very high level of personalisation.

Figures 2 and 3 represent the emergence of personal avatars to represent members and the process of "making friends."

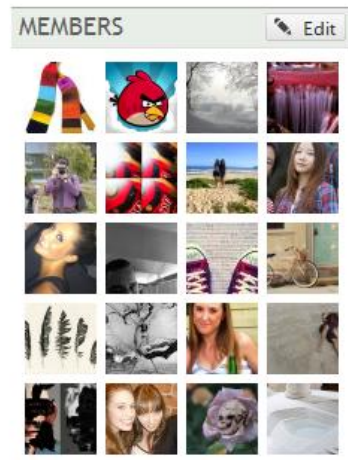

Figure 2. Avatar images

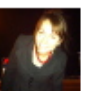

Belinda Hoang and Laura Ashleigh Robinson are now friends

Figure 3. Public display of friending 


\section{Survey Questions}

A review of research in social media for education reveals a clear lack of studies that have specifically investigated the effectiveness of inclusive learning through student social interaction in a blended course environment. There is a need for more in-depth studies that examine the effectiveness and inclusiveness of online socialised learning, particularly when combined with face-to-face contact. This study, therefore, has aimed to examine how student perceptions of blended learning environments, social interaction, and overall satisfaction are related, as well as identifying critical issues such as privacy and disclosure, information management. A survey was issued to the students and staff containing a combination of questions ranging from multiple choice and short answer questions, to psychometric scale items (Table 1).

Table 1

Survey Questions

\begin{tabular}{cl}
\hline \multicolumn{1}{c}{ Survey Question } & \multicolumn{1}{c}{ Question Type } \\
\hline Have you used social media before? e.g., Facebook, Twitter, Blog. & Multiple Choice \\
$\bullet \quad$ If yes, what social media have you used before? & Short Answer \\
Outside the educational environment, do you use social media? & Multiple Choice \\
Prior to Ning, did you use any other online learning environment for & Multiple Choice
\end{tabular}
educational purposes?

- If yes, what did you use?

Do you chat/comment/email other students in Ning?

The Ning environment helped me build a sense of community (interaction) amongst the students.

The Ning environment helped build a closer relationship with tutors.

Using Ning improved the way I interacted with my peers/tutors in studio,

Using Ning helped me feel more connected with the course.

Using Ning helped me to develop my communication skills.

Using Ning helped me keep more informed about the course.

Using Ning helped me better prepare for studio.

Using Ning helped me progress my design work between face-to-face studios.

I prefer: (Face-to-Face Only, Online Only, A combination of the two). The combination of online and face-to-face approach had a positive impact on my progress in this course.

The online component will help achieve a better grade in the course.

Using Ning helped me reflect on what I was learning.

Using Ning improved my design skills in general.

Compared to your previous experience with online learning, what was different this time using Ning?

The online environment developed my ability to express and share my ideas.

Using Ning helped me improve my ability to work with a group.

I $\log$ into Ning...(frequency)

I do the following in Ning (multiple options to measure activity).

The online component allowed me the flexibility to study at times that suited me.

Having this flexibility had a significant impact on my ability to

Short Answer

Multiple Choice

Psychometric Scale

Psychometric Scale

Psychometric Scale

Psychometric Scale

Psychometric Scale

Psychometric Scale

Psychometric Scale

Psychometric Scale

Multiple Choice

Psychometric Scale

Psychometric Scale

Psychometric Scale

Psychometric Scale

Short Answer

Psychometric Scale

Psychometric Scale

Multiple Choice

Multiple Choice

Psychometric Scale

Psychometric Scale complete assessments.

Having this flexibility had a significant impact on my ability to manage

Psychometric Scale 
my time effectively.

Do you upload ALL of your ideas \& design development, or do you

Multiple Choice retain some aspects for one-to-one discussion with your tutor in studio? If you do not upload all of your ideas \& design development, what are your reasons for retaining them?

I am comfortable with publishing my work online.

Short Answer

I am able to seek and receive feedback efficiently using the Ning access to the tutors.

I am more likely to comment on a student's work online than face-toface.

I am more comfortable presenting my work online than verbally.

Psychometric Scale

Psychometric Scale

Psychometric Scale

Psychometric Scale

I feel comfortable providing honest feedback on other students' work.

Psychometric Scale

I prefer to receive feedback. (Face-to-Face Only, Online Only, A

Multiple Choice

combination of the two).

If I am lost, I... (multiple options to measure reaction).

Overall, the online component (Ning) added value to my face-to-face interactions (e.g., lectures, studio, group projects).

I would prefer to have this course... (Face-to-Face Only, Online Only, Psychometric Scale A combination of the two).

I would like to see the following components online (multiple options to measure preferences).

\author{
Multiple Choice \\ Psychometric Scale
}

Multiple Choice

\section{Survey Results}

Of the students surveyed $(n=92)$, the average question response rate was $99 \%$. Student responses to the multiple-choice questions were measured as a percentage of the response count. Multiple choice questions were made mandatory so these questions had a 100\% response count. Students' responses to the more open-ended short answer questions were analysed to discover any patterns and common issues. These questions were optional, so response counts are provided for further clarification.

Student's responses to the psychometric scale questions were measured with a rating average, calculated from allocated scores for each scale. Five scales were presented with these questions: $\mathrm{SA}=$ Strongly Agree (Score of 5), MA=Mildly Agree (Score of 4), NAD=Neither Agree or Disagree (Score of 3), MD=Mildly Disagree (Score of 2), SD=Strongly Disagree (Score of 1). Thus, a more "approving" response to the survey statement would yield a higher rating average, with 5 being the maximum. A more "opposing" response to the statement would correspondingly yield a lower rating average, with 1 being the minimum. These questions were not made mandatory, so the response counts are provided for further clarification. Students' overall satisfaction and experience with the Ning environment was analysed using a series of psychometric scale questions (Table 2) 
Table 2

Students' evaluation of their experience using the Ning network

\begin{tabular}{|c|c|c|c|c|c|c|c|}
\hline \multirow{2}{*}{ Survey Question (Psychometric) } & $\mathrm{SA}^{1}$ & $\mathrm{MA}^{2}$ & $\mathrm{~N}^{3}$ & $\mathrm{MD}^{4}$ & $\mathrm{SD}^{5}$ & $\mathrm{RA}^{6}$ & $\mathrm{RC}^{7}$ \\
\hline & $n(\%)$ & $n(\%)$ & $n(\%)$ & $n(\%)$ & $n(\%)$ & $n$ & $n$ \\
\hline $\begin{array}{l}\text { Using Ning helped me to develop my } \\
\text { communication skills }\end{array}$ & $\begin{array}{c}18 \\
(19.78)\end{array}$ & $\begin{array}{c}37 \\
(40.66)\end{array}$ & $\begin{array}{c}25 \\
(27.47)\end{array}$ & $\begin{array}{c}9 \\
(9.89)\end{array}$ & $\begin{array}{c}2 \\
(2.2)\end{array}$ & 3.7 & 91 \\
\hline $\begin{array}{l}\text { Using Ning helped me keep more } \\
\text { informed about the course }\end{array}$ & $\begin{array}{c}35 \\
(38.46)\end{array}$ & $\begin{array}{c}40 \\
(43.96)\end{array}$ & $\begin{array}{c}15 \\
(16.48)\end{array}$ & $\begin{array}{c}0 \\
(0)\end{array}$ & $\begin{array}{c}1 \\
(1.1)\end{array}$ & 4.2 & 91 \\
\hline $\begin{array}{l}\text { Using Ning helped me better prepare } \\
\text { for studio }\end{array}$ & $\begin{array}{c}41 \\
(45.05)\end{array}$ & $\begin{array}{c}39 \\
(42.86)\end{array}$ & $\begin{array}{c}7 \\
(7.69)\end{array}$ & $\begin{array}{c}3 \\
(3.3)\end{array}$ & $\begin{array}{c}1 \\
(1.1)\end{array}$ & 4.3 & 91 \\
\hline $\begin{array}{l}\text { Using Ning helped me progress my } \\
\text { design work between face-to-face } \\
\text { studios }\end{array}$ & $\begin{array}{c}40 \\
(43.96)\end{array}$ & $\begin{array}{c}36 \\
(39.56)\end{array}$ & $\begin{array}{c}10 \\
(10.99)\end{array}$ & $\begin{array}{c}3 \\
(3.3)\end{array}$ & $\begin{array}{c}2 \\
(2.2)\end{array}$ & 4.2 & 91 \\
\hline $\begin{array}{l}\text { The combination of online and face- } \\
\text { to-face approach had a positive } \\
\text { impact on my progress in this course }\end{array}$ & $\begin{array}{c}39 \\
(42.86)\end{array}$ & $\begin{array}{c}40 \\
(43.96)\end{array}$ & $\begin{array}{c}9 \\
(9.89)\end{array}$ & $\begin{array}{c}2 \\
(2.2)\end{array}$ & $\begin{array}{c}1 \\
(1.1)\end{array}$ & 4.3 & 91 \\
\hline $\begin{array}{l}\text { The online component will help } \\
\text { achieve a better grade in the course }\end{array}$ & $\begin{array}{c}27 \\
(29.67)\end{array}$ & $\begin{array}{c}32 \\
(35.16)\end{array}$ & $\begin{array}{c}24 \\
(26.37)\end{array}$ & $\begin{array}{c}6 \\
(6.59)\end{array}$ & $\begin{array}{c}2 \\
(2.2)\end{array}$ & 3.8 & 91 \\
\hline $\begin{array}{l}\text { Using Ning helped me reflect on what } \\
\text { I was learning }\end{array}$ & $\begin{array}{c}34 \\
(37.36)\end{array}$ & $\begin{array}{c}37 \\
(40.66)\end{array}$ & $\begin{array}{c}14 \\
(15.38)\end{array}$ & $\begin{array}{c}5 \\
(5.49)\end{array}$ & $\begin{array}{c}1 \\
(1.1)\end{array}$ & 4.1 & 91 \\
\hline $\begin{array}{l}\text { Using Ning improved my design } \\
\text { skills in general }\end{array}$ & $\begin{array}{c}22 \\
(24.18)\end{array}$ & $\begin{array}{c}33 \\
(36.26)\end{array}$ & $\begin{array}{c}22 \\
(24.18)\end{array}$ & $\begin{array}{c}9 \\
(9.89)\end{array}$ & $\begin{array}{c}5 \\
(5.49)\end{array}$ & 3.6 & 91 \\
\hline $\begin{array}{l}\text { Using Ning helped me improve my } \\
\text { ability to work with a group }\end{array}$ & $\begin{array}{c}9 \\
(9.89)\end{array}$ & $\begin{array}{c}24 \\
(26.37)\end{array}$ & $\begin{array}{c}38 \\
(41.76)\end{array}$ & $\begin{array}{c}17 \\
(18.68)\end{array}$ & $\begin{array}{c}3 \\
(3.3)\end{array}$ & 3.2 & 91 \\
\hline $\begin{array}{l}\text { I am able to seek and receive } \\
\text { feedback efficiently using the Ning } \\
\text { access to the tutors }\end{array}$ & $\begin{array}{c}18 \\
(20.00)\end{array}$ & $\begin{array}{c}40 \\
(44.44)\end{array}$ & $\begin{array}{c}18 \\
(20.00)\end{array}$ & $\begin{array}{c}8 \\
(8.89)\end{array}$ & $\begin{array}{c}6 \\
(6.67)\end{array}$ & 3.6 & 90 \\
\hline $\begin{array}{l}\text { I am more likely to comment on a } \\
\text { student's work online than face-to- } \\
\text { face }\end{array}$ & $\begin{array}{c}2 \\
(2.22)\end{array}$ & $\begin{array}{c}15 \\
(16.67)\end{array}$ & $\begin{array}{c}33 \\
(36.67)\end{array}$ & $\begin{array}{c}24 \\
(26.67)\end{array}$ & $\begin{array}{c}16 \\
(17.78)\end{array}$ & 2.6 & 90 \\
\hline $\begin{array}{l}\text { Overall the online component (Ning) } \\
\text { added value to my face-to-face } \\
\text { interactions (lectures, studio, group } \\
\text { projects, etc.) }\end{array}$ & $\begin{array}{c}27 \\
(30.00)\end{array}$ & $\begin{array}{c}45 \\
(50.00)\end{array}$ & $\begin{array}{c}13 \\
(14.44)\end{array}$ & $\begin{array}{c}4 \\
(4.44)\end{array}$ & $\begin{array}{c}1 \\
(1.11)\end{array}$ & 4 & 90 \\
\hline
\end{tabular}

Notes to Table 2.

1. $\mathrm{SA}=$ Strongly Agree

2. $\mathrm{MA}=$ Mildly Agree

3. $\quad \mathrm{N}($ Neutral $)=$ Neither Agree or Disagree

4. $\mathrm{MD}=$ Mildly Disagree

5. $\mathrm{SD}=$ Strongly Disagree

6. $\mathrm{RA}=$ Rating Average

7. $\mathrm{RC}=$ Response Count

\section{Students' Preferences for Online Components}

Two questions were used to measure the students' preference for online components, and the three for learning environments. The first question was comprised of multiple choice items with a list of components that commonly occur in a design studio, viz., Lectures, time with tutor, interim presentations, critiques, final presentations, feedback from tutor, announcements and discussions Components such as lectures, feedback from tutor and discussions yielded the highest preferences. Figure 4 shows the responses as a bar graph. 


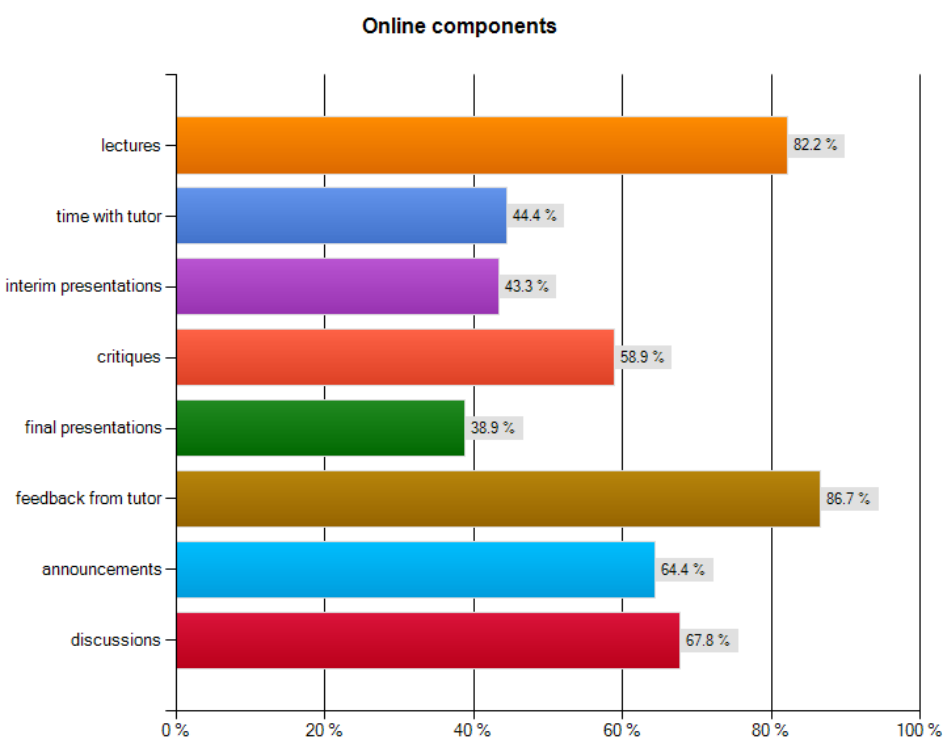

Figure 4. Students' preferred online learning experiences

The second item aimed to verify the students' preference for teaching mode. Three options were given: online, face-to-face and blended (combined face-to-face and online). An overwhelmingly $78 \%$ preferred the blended face-to-face and online environment with $4.4 \%$ preferring a completely online environment and $17.8 \%$ preferring face-to-face only. The results, presented in Figure 5, clearly show that, from a students' perspective, a blended learning environment is strongly favoured.

"I would prefer to have this course..."

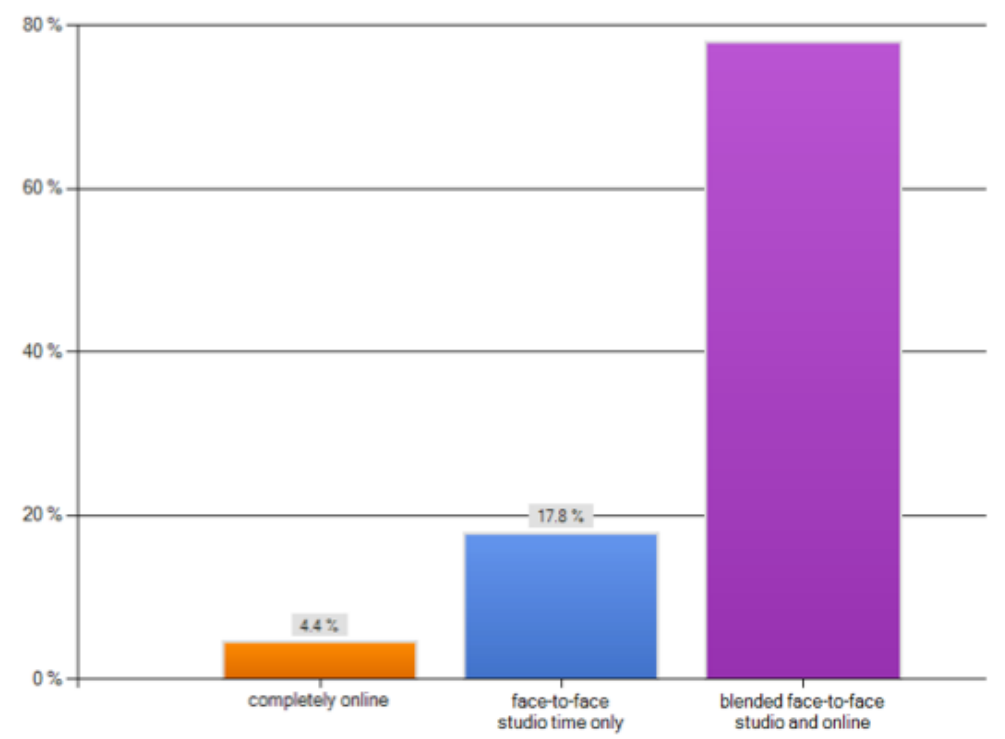

Figure 5. Students' preferred online learning mode 


\section{Flexible Modes and Personal Management}

Many students reported time flexibility and convenience as an advantage of the online environment. In the psychometric scale questions about flexibility, most responded with either a MA (Mildly Agree) or N (Neutral, neither Agree nor Disagree). This suggests that the online component offers a degree of time flexibility and convenience, but is not a strong asset (Table 3).

Table 3

Students' evaluation of the impact on time flexibility

\begin{tabular}{|c|c|c|c|c|c|c|c|}
\hline \multirow{2}{*}{ Survey Question (Psychometric) } & $\mathrm{SA}^{1}$ & $\mathrm{MA}^{2}$ & $\mathrm{~N}^{3}$ & $\mathrm{MD}^{4}$ & $\mathrm{SD}^{5}$ & $\mathrm{RA}^{6}$ & $\mathrm{RC}^{7}$ \\
\hline & $n(\%)$ & $n(\%)$ & $n(\%)$ & $n(\%)$ & $n(\%)$ & $n$ & $n$ \\
\hline $\begin{array}{l}\text { The online component allowed me } \\
\text { the flexibility to study at times that } \\
\text { suited me }\end{array}$ & $\begin{array}{c}19 \\
(20.88)\end{array}$ & $\begin{array}{c}29 \\
(31.87)\end{array}$ & $\begin{array}{c}32 \\
(35.16)\end{array}$ & $\begin{array}{c}8 \\
(8.79)\end{array}$ & $\begin{array}{c}3 \\
(3.3)\end{array}$ & 3.6 & 91 \\
\hline $\begin{array}{l}\text { Having this flexibility had a } \\
\text { significant impact on my ability to } \\
\text { complete assessments }\end{array}$ & $\begin{array}{c}14 \\
(15.38)\end{array}$ & $\begin{array}{c}32 \\
(35.16)\end{array}$ & $\begin{array}{c}31 \\
(34.07)\end{array}$ & $\begin{array}{c}10 \\
(10.99)\end{array}$ & $\begin{array}{c}4 \\
(4.4)\end{array}$ & 3.5 & 91 \\
\hline $\begin{array}{l}\text { Having this flexibility had a } \\
\text { significant impact on my ability to } \\
\text { manage my time effectively }\end{array}$ & $\begin{array}{c}13 \\
(14.29)\end{array}$ & $\begin{array}{c}33 \\
(36.26)\end{array}$ & $\begin{array}{c}29 \\
(31.87)\end{array}$ & $\begin{array}{c}13 \\
(14.29)\end{array}$ & $\begin{array}{c}3 \\
(3.3)\end{array}$ & 3.4 & 91 \\
\hline
\end{tabular}

Notes to Table 3.

1. $\mathrm{SA}=$ Strongly Agree

2. $\mathrm{MA}=$ Mildly Agree

3. $\quad \mathrm{N}($ Neutral $)=$ Neither Agree or Disagree

4. $\mathrm{MD}=$ Mildly Disagree

5. $\mathrm{SD}=$ Strongly Disagree

6. $\mathrm{RA}=$ Rating Average

7. $\mathrm{RC}=$ Response Count

A short answer expansion of these questions reveals feedback and staff contact as the primary benefit gained from outside class time:

- You are able to have contact with your tutor and receive advice and/or feedback twice a week instead of just once, which enables me to progress faster.

- Having extra time outside of uni to get feedback with design studio.

- I can't imagine Design Studio without it - it is such a help to know midweek whether there is something to improve on, or just to ask simple questions that would not be answered until the next week otherwise. It's fantastic in my opinion. It also allows you to express your ideas more between classes in order to make sure you fully get your point across. You can forget things easily in studio itself.

Although some responses stated a different management of time:

- ... like Facebook - too addictive.

- ... I constantly log on too much as is starting to feel like Facebook. I feel as if I'm procrastinating,

- $\quad$... the private (social) chat is not popping out like Facebook, so sometimes we are not realising there's a message.

\section{Students' Online Interaction and Behaviour}

A multiple-choice question, listing 9 options, was used to review the actions of students online. Options included: submit my work, look at other students' work, look at other students' profiles, change my own profile, read comments and feedback, post comments or suggestions, chat to other students, email students or tutors, check to see what it new. Figure 6 summarises the students' responses as a bar graph. 


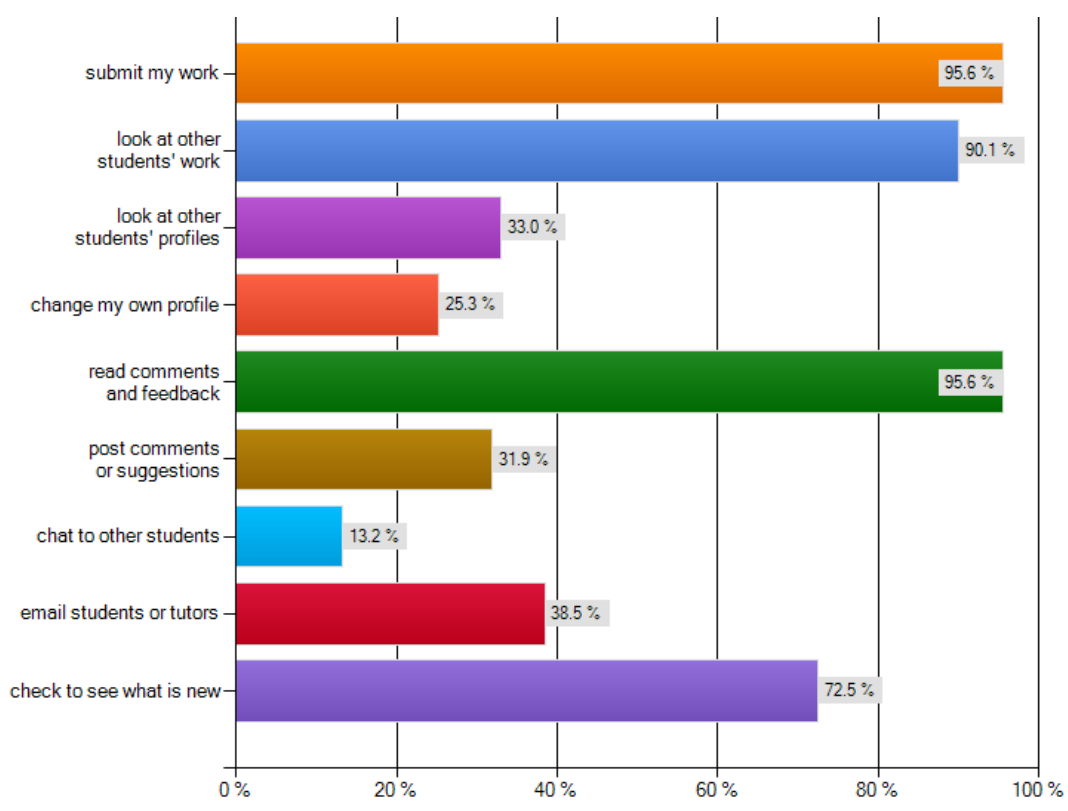

Figure 6. Actions of students online

The main activity was submitting work $(95.60 \%)$. They also predominantly looked at other students' work $(90.1 \%)$ and read comments and feedback online $(95.6 \%)$. Students also indicated they logged into Ning to "check to see what is new" (72.5\%). A minority used the Ning to chat to other students $(13.2 \%)$ or to email students or tutors $(38.5 \%)$.

\section{Equity and inclusion}

Students' perceptions of community, inclusion and level of comfort with using the Ning environment were evaluated using a range of psychometric scale questions (Table 4).

Table 4

Students' evaluation of the sense of community and inclusion

\begin{tabular}{lccccccc}
\hline \multicolumn{1}{c}{ Survey Question (Psychometric) } & $\mathrm{SA}^{1}$ & $\mathrm{MA}^{2}$ & $\mathrm{~N}^{3}$ & $\mathrm{MD}^{4}$ & $\mathrm{SD}^{5}$ & $\mathrm{RA}^{6}$ & $\mathrm{RC}^{7}$ \\
\cline { 2 - 7 } & $n(\%)$ & $n(\%)$ & $n(\%)$ & $n(\%)$ & $n(\%)$ & $n$ & $n$ \\
\hline The Ning environment helped me & 15 & 43 & 23 & 8 & 2 & 3.7 & 91 \\
build a sense of community & $(16.48)$ & $(47.25)$ & $(25.27)$ & $(8.79)$ & $(2.2)$ & & \\
(interaction) amongst the students & & & & & & & \\
The Ning environment helped build a & 21 & 41 & 19 & 7 & 3 & 3.8 & 91 \\
closer relationship with tutors & $(23.08)$ & $(45.05)$ & $(20.88)$ & $(7.69)$ & $(3.3)$ & & \\
Using Ning improved the way I interacted & 21 & 44 & 22 & 3 & 1 & 3.9 & 91 \\
with my peers/tutors in studio & $(23.08)$ & $(48.35)$ & $(24.18)$ & $(3.3)$ & $(1.1)$ & & \\
Using Ning helped me feel more & 32 & 38 & 16 & 3 & 2 & 4 & 91 \\
connected with the course & $(35.16)$ & $(41.76)$ & $(17.58)$ & $(3.3)$ & $(2.2)$ & & \\
The online environment developed my & 30 & 46 & 14 & 0 & 1 & 4.1 & 91 \\
ability to express and share my ideas & $(32.97)$ & $(50.55)$ & $(15.38)$ & $(0)$ & $(1.1)$ & & \\
I am comfortable with publishing my & 24 & 38 & 18 & 9 & 2 & 3.8 & 91 \\
work online & $(26.37)$ & $(41.76)$ & $(19.78)$ & $(9.89)$ & $(2.20)$ & & \\
I am more comfortable presenting my & 21 & 20 & 26 & 14 & 9 & 3.3 & 90 \\
work online than verbally & $(23.33)$ & $(22.22)$ & $(28.89)$ & $(15.56)$ & $(10.0)$ & & \multirow{2}{*}{90} \\
I feel comfortable providing honest & 8 & 30 & 35 & 13 & 4 & 3.3 & 90 \\
feedback on other students' work & $(8.89)$ & $(33.33)$ & $(38.89)$ & $(14.44)$ & $(4.44)$ & & \\
\hline
\end{tabular}


Notes to Table 4.

1. $\mathrm{SA}=$ Strongly Agree

2. $\mathrm{MA}=$ Mildly Agree

3. $\quad \mathrm{N}($ Neutral $)=$ Neither Agree or Disagree

4. $\mathrm{MD}=$ Mildly Disagree

5. $\mathrm{SD}=$ Strongly Disagree

6. $\mathrm{RA}=$ Rating Average

7. $\mathrm{RC}=$ Response Count

As can be noted in Table 4, the online studio environment assisted students in developing a sense of connectedness, with over $77 \%$ of survey respondents agreeing that it helped them to feel more connected to the course overall. For students, connectedness was important not only in terms of connectedness to each other and the course, but also in terms of connectedness to their own design process:

- the best thing about Ning was connecting with other students who are in the same position as you, learning from them as well as re-reading your thoughts.

- being able to learn from your peers as well as receiving feedback and learning from other people's feedback as well.

- $\quad$ being able to get feedback more frequently and reading other students feedback was also beneficial e.g. reading another person's feedback would help me to think about specific issues in my design I might need to improve upon.

\section{Disclosure and privacy}

Students' conduct and judgment about the online publication of their creative ideas was analysed using three multiple-choice questions and associated short answer responses. Results reveal that the majority of students deliberately withhold creative work when publishing online, choosing to retain the work for face-to-face contact with their tutors (Figure 7). Although most students upload their work on completion, over $40 \%$ of students withheld their publication until the last day or until they saw evidence of other students work first (Figure 8). This strongly suggests either a concern over intellectual theft, or a lack of confidence in the standard of work.

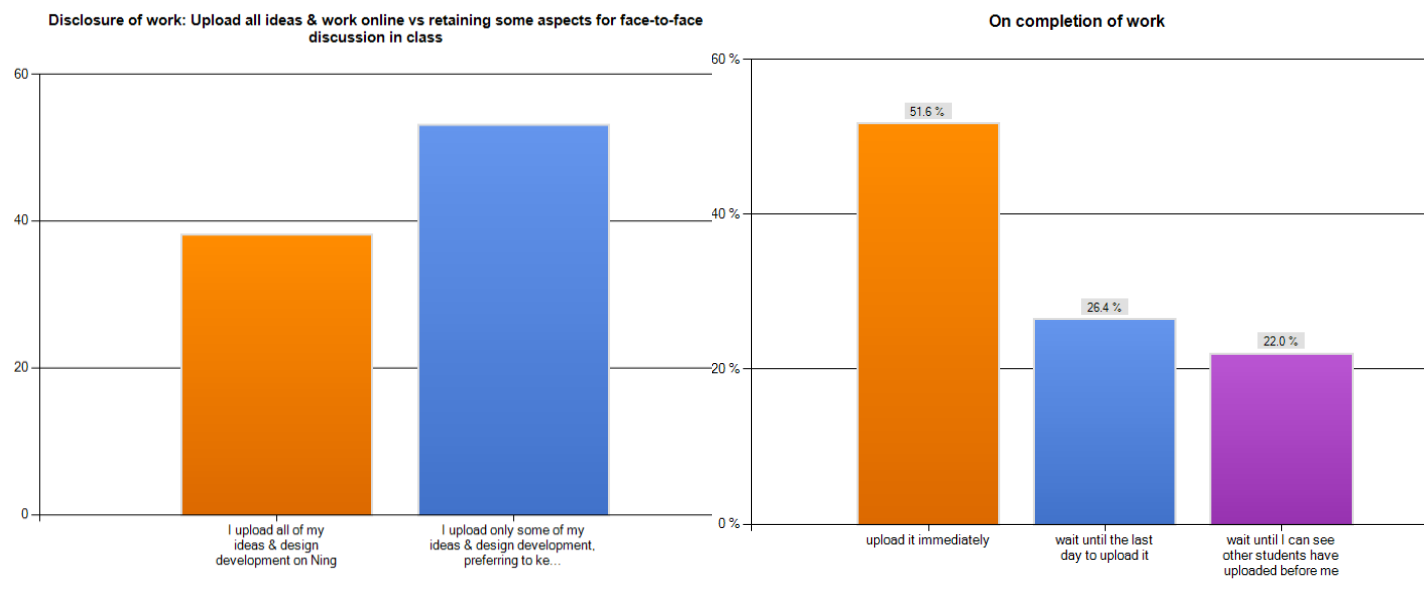

Figure 7. Extent of disclosure during development of work
Figure 8. Extent of disclosure on completion of work

The third question aimed to evaluate student behaviour when a lack of direction occurs. Over $40 \%$ stated they looked at other students work when they are lost, rather than seek staff advice. This may suggest a trend towards peer copying, and supports students' concerns of intellectual theft. An associated short answer question verifies this: 
- I don't upload all of my work because of:

- fear that other students will steal ideas - have seen my own concepts 'recycled' by other students word for word.

- I don't want others to 'borrow' it.

- at early stages, competition between students is a big factor.

Figure 9 summarises the strategies students used when they are "lost." One of these was to view others' work (43.3\%) with some of these asking the other student first (26.7\%). About one third of students indicated that they would ask a tutor (26.7\%) or wait for the tutorial (3.3\%).

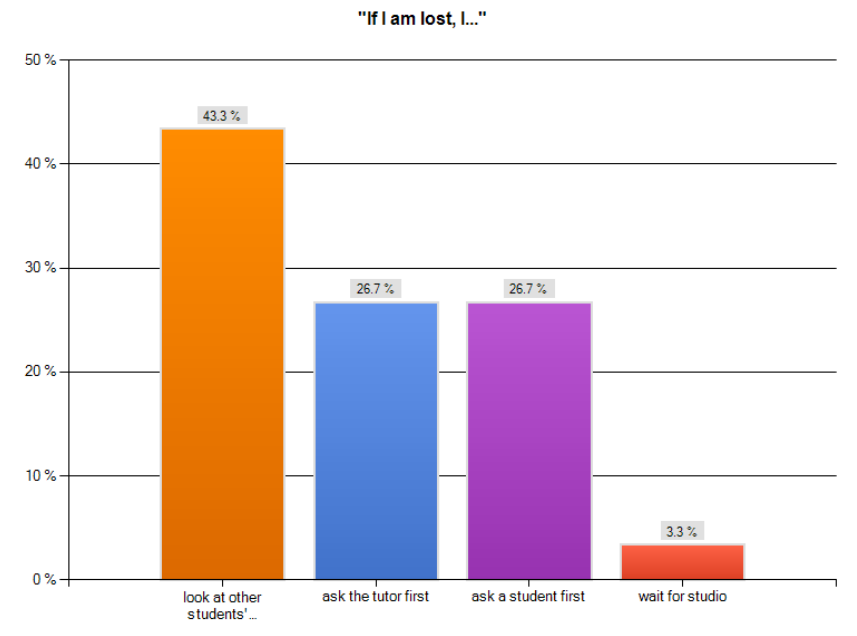

Figure 9. Student strategy to overcome difficulties

\section{Conclusion: Socialisation, Trust and the Design Process}

This preliminary study indicates that a social network appears to have the potential to influence and change students' interactions and behaviour. However, it has been made apparent that the interactions that occur within the network are more observational, with the majority of students using the network to observe each other's behaviour and publications rather than to discuss and comment. Although peer support was expressed in some comments, most of the social participation was more passive rather than the active involvement seen in other social networks such as Facebook. However, this passive social behaviour is clearly beneficial for students, with most of them stating they gain a deeper understanding of the course content and each other by observing. There is also evidence to support social networks as an effective environment for facilitating student familiarity and sense of inclusion. Students have stated they are better prepared, settled and informed about the course through the combined use of online and face-to-face contact. The large majority assert they are more connected and comfortable with the online environment, and clearly value the network as a component of their course.

For the beginning student, the design studio as a place of learning is often seen as a mystifying setting. Architectural historian Jeffrey Karl Ochsner (2000) noted that part of this mystery lies in the unbounded nature of design enquiry that is "fundamentally about learning 'trust' in a process a process of discovery, the endpoint of which cannot be initially be known or even predicted" (p. 195).

Degrees of connectedness and trust can be developed through social relations occurring in an educational environment. Blended learning approaches that combine both face-to-face teaching and on-line environments encourage opportunities for socialisation, connectedness and trust. For students, the on-line studio environment assisted in developing a sense of trust in the undefined 
nature of the design process, with over $78 \%$ of survey respondents agreeing that it helped them reflect on what they were learning:'

- $\quad$ The best thing about Ning is:

- I can see clearly of how my work has been developed.

- Connecting with other students who are in the same position as you, learning from them as well as re-reading your thought.

A key aspect of the visibility of theirs and their peer's design development was that it made the process of design visible: The best thing about using Ning is the design process can be seen.

It is clear that the integration of Web 2.0 technologies into conventional teaching approaches is able to effectively support the changing student online literacies and engagement. It is, however, important to note that there are implications that arise from using the online environment for assessment. The public nature of student blogs in the online environment however, has the potential to erode trust in between students. Issues such as privacy, creative disclosure and intellectual property become strong concerns that repress more active online social behaviour.

Using social networks in a blended structure does have clear advantages, where the benefits of both face-to-face and online contact provide a much more inclusive teaching environment than one only. Social interaction is shown to add value to a student's learning experience through participation and publication, although there is scope to re-think the use of social networks for assessment. In this complex and shifting area, the transparency and flexibility of the online environment seem to raise more challenges than solutions. To progress higher education in the $21^{\text {st }}$ century, we need an understanding of the learners who will be occupying this landscape and their needs. Hybrid teaching environments that take advantage of their developed online literacy are much more able to connect to their diverse patterns of information and knowledge management, scholarly publishing and learning.

\section{References}

Alexander, B. (2006). Web 2.0: A new wave of innovation for teaching and learning. Learning, $41(2), 32-44$.

Andersen, P. (2007). What is Web 2.0?: ideas, technologies and implications for education. JISC Technology \& Standards Watch. Retrieved from http://www.jisc.ac.uk/media/documents/techwatch/tsw0701b.pdf

boyd, D. M., \& Ellison, N. B. (2008). Social network sites: Definition, history, and scholarship. Journal of Computer Mediated Communication, 13(1), 210-230.

Collis, B., \& Moonen, J. (2002). Flexible learning in a digital world. Open Learning: The Journal of Open and Distance Learning, 17(3), 217-230.

Donath, J., \& boyd, D. (2004). Public Displays of Connection. BT Technology Journal, 22(4), 7182.

Driscoll, M. (2002). Blended Learning: Let's get beyond the hype. LTI Newsline: Learning and Training Innovation. Retrieved from http://www.ltinewsline.com/ltimagazine/article/articleDetail.jsp?id=11755

Jusoff, K., \& Khodabandelou, R. (2009). Preliminary study on the role of social presence in blended learning environment in higher education. International Education Studies, 2(4), 7986.

Ochsner, J. K. (2000). Behind the mask: A psychoanalytic perspective on interaction in the design studio. Journal of Architectural Education, 53(4), 194-206. 
Osborne, L., Franz, J., Savage, S., \& Crowther, P. (2011). Dichotomy in the design studio: Adapting to new blended learning environments. ICERI2011 Proceedings CD, IATED, Madrid, Spain, pp. 5579-5588.

Prensky, M. (2001). Digital natives, digital immigrants Part 1. On the horizon, 9(5), 1-6.

Richardson, J. C., \& Swan, K. (2003). Examining social presence in online courses in relation to students' perceived learning and satisfaction. Journal of Asynchronous Learning Networks, $7(1), 68-88$.

Roberts, G. R. (2005). Technology and learning expectations of the net generation. In D.G. Oblinger \& J.L. Oblinger (Eds.), Educating the net generation (pp. 3.1-3.7). Washington, DC: Educause.

Rourke, L., Anderson, T., Garrison, D. R., \& Archer, W. (1999). Assessing social presence in asynchronous text-based computer conferencing. Journal of Distance Education, 14, (3), 5170.

Schnabel, M. C., \& Ham, J. J. (2011). The social network virtual design studio: Integrated Design learning using blended learning environments. Proceedings of the 16th International Conference on Computer-Aided Architectural Design Research in Asia, pp. 589-598.

Tu, C. H. (2002). The measurement of social presence in an online learning environment. International Journal on E-learning, 1(2), 34-45.

Yildiz, S. (2009). Social Presence in the Web-Based Classroom. Journal of Studies in International Education, 13(1), 46.

Copyright ( 2013 Russell Rodrigo and Tam Nguyen 